\title{
Upaya Pencapaian Angka Kelulusan Uji Kompetensi Profesi Ners Melalui Pendekatan Metode Peer-teaching
}

\author{
Irwan Hadi' ${ }^{\text {, Harlina Putri², Misroh Mulianingsih }}{ }^{3}$ \\ 1,2 Departemen Dasar Keperawatan dan Keperawatan dasar, STIKES YARSI Mataram \\ 3 Departemen Anak dan Maternitas, STIKES YARSI Mataram
}

\begin{tabular}{|c|c|}
\hline Article Info & Abstract \\
\hline $\begin{array}{l}\text { Article History: } \\
\text { Diterima } 19 \text { April } 2020 \\
\text { Key words: } \\
\text { Uji Kompetensi Ners; Peer- } \\
\text { teaching }\end{array}$ & $\begin{array}{l}\text { Angka kelululusan Uji Kompetensi Ners di Indonesia belum optimal. Peer- } \\
\text { teaching merupakan metode pembelajaran dengan menggunakan teman } \\
\text { sebaya sebagai fasilitator. Hubungan antara teman sebaya lebih dekat dan } \\
\text { lebih aktif dibandingkan dengan hubungan antara fasilitator lain. Penelitian } \\
\text { ini bertujuan untuk meningkatkan pencapain kelulusan uji kompetensi } \\
\text { profesi Ners dengan pendekatan Peer-teaching. Jenis penelitian adalah quasi } \\
\text { eksperimen. Penelitian dilaksanakan di STIKES Yarsi Mataram dengan } \\
\text { subjek penelitian yang didapatkan melalui tehnik purposive sampling. Hasil } \\
\text { penelitian telah menunjukkan bahwa pendekatan peer-teaching mempunyai } \\
\text { efektivitas dalam peningkatan kelulusan uji kompetensi dengan nilai p } \\
\text { value=0,000 dengan tingkat kekuatan pengaruh sebesar } 73,8 \% \text {. Peran } \\
\text { teman sebaya sebagai strategi peningkatan kemampuan pemahaman uji } \\
\text { kompetensi sangat berpengaruh terhadap peningkatan kelulusan uji } \\
\text { kompetensi. }\end{array}$ \\
\hline
\end{tabular}

\section{PENDAHULUAN}

Kebutuhan tenaga perawat mengalami peningkatan seiring peningkatan jumlah penduduk Indonesia. Berdasarkan Pusat data dan Informasi Kementerian Kesehatan RI tahun 2016 menyebutkan rasio perawat terhadap 100.000 penduduk Indonesia pada tahun 2014 sebesar 94,07 perawat per 100.000 penduduk dan mengalami penurunan di tahun 2015 menjadi 87,65 perawat per 100.000 penduduk. Namun angka tersebut masih dikatakan jauh dari target yang telah ditetapkan dalam rencana strategis kementerian kesehatan tahun 2015-2019 yaitu 180 perawat per 100.000 penduduk. Badan pengembangan dan Pemberdayaan Sumber Daya Manusia Kesehatan (BPPSDMK) menyebutkan presentase jumlah perawat yang tersebar hanya pada angka $29,66 \%$ dari total keseluruhan tenaga kesehatan yang ada di Indonesia per Desember 2016 (Kemenkes RI, 2017).

Kondisi tersebut banyak disebabkan oleh permasalahan distribusi tenaga, ketidakjelasan dalam melaksanakan kewenangan praktik mandiri maupun kolaborasi, keterbatasan dalam mendapatkan hak-hak serta ketidaktercapaian perawat dalam mencapai

Corresponding author:

Irwan Hadi

irwanhadi711@gmail.com

Jurnal Kepemimpinan dan Manajemen Keperawatan, Vol 3 No 1, Mei 2020

DOI: http://dx.doi.org/10.26594/jkmk.v3.i1.432

e-ISSN 2621-5047 
kompetensi tenaga perawat itu sendiri. Sebagai sebuah profesi yang berbasis pada kompetensi yang melaksanakan asuhan keperawatan, seorang perawat dituntut untuk memenuhi kualifikasinya dengan memiliki Surat Tanda Registrasi (STR) sebagai bentuk pengakuan Majelis Tenaga Kesehatan Indonesia (MTKI). STR tersebut diperoleh dengan syarat memiliki sertifikat kompetensi yang didapatkan setelah lulus mengikuti uji kompetensi.

Uji kompetensi sendiri mengalami kemunduran dalam jumlah lulusan tiap periodenya. Secara nasional jumlah peserta ukom yang tidak lulus pada periode IV tahun 2015 sebanyak 4.025 sedangkan yang lulus sebanyak 6.223, periode $V$ tahun 2016 tidak lulus sebanyak 7.872 sedangkan yang lulus sebanyak 7.466, periode VI tahun 2016 tidak lulus sebanyak 9.582 sedangkan yang lulus 7.938, periode VII tahun 2017 tidak lulus sebanyak 10.980 sedangkan yang lulus sebanyak 8.093, periode VIII tahun 2017 tidak lulus sebanyak 8.475 sedangkan yang lulus 5.319 dan periode IX tahun 2017 tidak lulus sebanyak 13.476 sedangkan yang lulus sebanyak 7.349 (Kemenristekdikti, 2017). Berbagai upaya telah dilakukan oleh Perguruan tinggi mulai dari diberlakukannya pembekalan seperti review materi asuhan keperawatan secara berkelompok, review soal uji kompetensi hingga mendatangkan pembicara luar untuk mendapatkan tips lulus uji kompetensi (Rahadian, 2018).

Kendala yang ditemukan pada saat pelaksanaan tersebut adalah keterbatasan jumlah para pembimbing yang tidak bisa meng-cover jumlah peserta, rendahnya motivasi peserta reteker dalam mengikuti pelaksanaan pembekalan, waktu yang terbatas dalam pelaksanaan pembekalan yaitu hanya seminggu sebelum uji kompetensi dilaksanakan serta penyampaian yang masih dilakukan dengan metode ceramah dari pihak pendidik (Mustika, Artanty, Harjanto, \& Ibrahim, 2019). Hal tersebut menjadikan proses pembekalan menjadi kurang efektif dan berakibat pada rendahnya tingkat lulusan uji kompetensi. Peran perguruan tinggi dalam uji kompetensi sangat penting terutama melalui perubaha strategi dalam pembelajaran (Krisdianto \& Kusumawati, 2019).

Menghadapi uji kompetensi pada tahun 2019 membutuhkan strategi dalam mencapai tingkat kelulusan maksimal. Kondisi dalam proses pendidikan singkat tersebut (pembekalan ukom) membutuhkan metode alternative dalam proses pelaksanaanya (Rahadian, 2018). Peer-teaching merupakan salah satu metode yang banyak digunakan di dunia pendidikan saat ini. Metode ini banyak digunakan oleh Negara-negara maju seperti Amerika Serikat, Kanada, Australia dan beberapa Negara berkembang seperti Malaysia dan Indoenesia. Di dunia kesehatan sendiri, metode peer-teaching dianggap dapat meningkatkan pencapaian kompetensi lulusan.

Penelitian yang dilakukan Fitria (2016) menyebutkan adanya efektivitas metode tutor sebaya terhadap pencapaian kompetensi asuhan persalinan normal pada pembelajaran laboratorium Prodi DIII Kebidanan UNUSA dengan perbedaan ratarata nilai kelompok kontrol dan kelompok intervensi sebesar 3,14. Penelitan serupa juga dilakukan oleh Nikmatul dengan tema metode peer-teaching yang dilakukan modifikasi dengan penggunaan video pada tahun 2014 memberikan manfaat berupa peningkatan interaksi dan kolaborasi antar mahasiswa keperawatan, peningkatan rasa percaya diri mahasiswa, penurunan kecemasan saat belajar, kebebasan berkomunikasi antar rekan, peningkatan motivasi belajar yang tinggi (diukur dengan CTPQ dan PTEQ), serta adanya dukungan yang lebih antar rekan (Lesmana, Wiharna, \& Sulaeman, 2016).

Penelitian tersebut juga, memperhatikan beberapa hal yaitu usia yang sepantaran menyebabkan kemampuan komunikasi dan manajemen pengajaran yang masih kurang 
dan jarak pengetahuan antara tutor dengan tutee dapat menurunkan ketercapaian tujuan pembelajaran. Berdasarkan temuan tersebut diatas maka kami menganggap perlunya dilakukan penelitian tentang "Upaya Pencapaian Angka Kelulusan Uji Kompetensi Profesi Ners Melalui Pendekatan Metode Peer-teaching ".

Tujuan penelitian ini adalah untuk mengetahui Keefektifitasan metode peerteaching terhadap pencapain kelulusan uji kompetensi Tahun 2019

\section{METODE}

Penelitian ini merupakan penelitian Quasy Eksperiment dengan menggunakan rancangan penelitian pre-eksperimen dengan pendekatan post test only control group design. Penelitian ini menggunakan rancangan tersebut untuk mengetahui pengaruh Pendekatan Peer-teaching terhadap pencapain kelulusan uji kompetensi Ners tahun 2019. Pelaksanaan Penelitian akan dilakukan di STIKES Yarsi Mataram program Profesi Ners sesuai dengan Jadwal uji Kompetensi yaitu periode Juli dan September. Subjek dalam penelitian ini adalah peserta yang mengikuti uji kompetensi yang berasal dari lulusan STIKES Yarsi Mataram tahun lulusan 2018 berdomisili di Kota Mataram dan Kabupaten Lombok Barat, mampu mengoperasikan komputer dan mengunakan Handphone berkoneksi internet dan bersedia mengikuti bimbingan Uji Kompetensi dalam penelitian.

Proses pengumpulan data dilakukan dengan menggunakan Alat ukur berupa lembar checklist, lembar observasi dan lembar panduan wawancara untuk mengetahui kemampuan peserta mengikuti uji kompetensi. Intervensi Peer-teaching dalam penelitian dilaksanakan sebanyak 3 kali setiap periode uji kompetensi yaitu sebelum dimulai proses bimbingan, pada saat proses bimbingan dan setelah proses bimbingan menggunakan peer-teaching. Subjek penelitian dilakukan proses bimbingan oleh teman sebayanya sesuai dengan jadwal yang telah ditetapkan.

Pelaksanaan penelitian dilakukan terlebih dahulu dengan meminta kesedian responden dengan menandatangni lembar persetujuan dan meminta komitemen bersama dengan harapan dapat berjalan dengan baik.

Analisis data yang digunakan dalam penelitian ini adalah Analisis Univariat dan Analisis Bivariat dengan Uji Wilcoxon. Analisa Data dilakukan untuk mengetahui efektifikas pendekatan peer-teaching terhadap pencapain kelulusan uji kompetensi dengan nilai signifikansi 0,01\%.

\section{HASIL}

Hasil penelitian ini menunjukkan bahwa karakteristik respnden berdasarkan jenis kelamin yaitu laki-laki sebanyak 15 orang (50\%) dan Perempuan sebanyak 15 orang (50\%). berdasarkan pekerjaan yaitu pegawai negrri sipil sebanyak 6 orang (20\%), Swasta sebanyak 9 orang (30\%) dan belum bekerja sebanyak 15orang (50\%). Berdasarkan umur didapatakn bahwa umur $>25$ tahun sebanyak 3 orang $(10 \%)$, 26-30 tahun sebanyak 18 orang (60\%) dan $>30$ tahun sebanyak 9 orang (30\%) berdaasarakan jumlah keikutsertaan uji kompetensi didapatkan 2-4 kali sebanyak 26 orang $(86 \%)$ dan 5-6 kali sebanyak 4 orang $(24 \%)$.

Hasil penelitian menunjukkan bahwa kemampuan pemahaman responden berada dalam kategori baik dan sangat baik. Hasil uji kompetensi menunjukkan bahwa masih terdapat beberapa responden yang tidak kompeten. 
Tabel 1

Distribusi Frekwensi Responden Kemampuan dan Hasil Uji Kompetensi Tahun 2019

\begin{tabular}{lcc}
\hline \multicolumn{1}{c}{ Indikator } & $\mathrm{f}$ & $\%$ \\
\hline Kemampuan pemahaman soal & & \\
1. Sangat Baik & 18 & 60 \\
2. Baik & 12 & 40 \\
3. Kurang Baik & 0 & 0 \\
\hline Kompetensi & & \\
1. Kompeten & 22 & 73.3 \\
2. Tidak Kompeten & 8 & 26.5 \\
\hline
\end{tabular}

Berdasarkan tabel diatas dijelaskan bahwa rata-rata nilai pemahaman uji kompetensi dengan pendekatan Peerteacing terhapat kelulusan uji kompetensi adalah 0,867 dan nilai standar deviasi pemahaman uji kompetensi dengan pendekatan Peerteacing terhapat kelulusanuji kompetensi adalah 0,346 . hasil uji statistic didapatkan bahwa nilai $\mathrm{p}$ value $=0,000$ dimana $p>0.05$ dan hasil korelasi didapatkan 0,739 maka dapat disimpulkan bahwa terdapat efektifitas peningkatan kelulusan uji kompetensi dengan pendekatan peer-teaching dengan tingkat hubungan yang sangat kuat.

Tabel 2

Hubungan antara kemampuan pemahaman Uji Kompetensi menggunakan pendekatan Peer-teacing dengan Kelulusan Uji Kompetensi

$$
\text { Indikator Koefisien } \quad \mathrm{p}
$$

\begin{tabular}{lll}
\hline $\begin{array}{l}\text { Pemahaman Uji } \\
\text { Kompetensi Dengan Peer }\end{array}$ & 0,739 & 0,000 \\
Teacing & & \\
\hline
\end{tabular}

\section{PEMBAHASAN}

\section{Kemampuan Memahami Uji Kompetensi melalui pendekatan peer teacing}

Berdasarkan tabel diatas didapatkan bahwa kemampuan pemahaman uji kompetensi dengan kategori sangat baik dengan pendekatan peer-teaching sebesar 18 orang. Dari hasil tersebut didapatkan keterlibatan teman sebaya dalam memberikan pemahaman uji kompetensi yang sangat baik. Keterlibatan teman sebaya dalam memberikan bimbingan dan mejadi fasilitator dalam pendekatan peer teacing sebagai strategi pembelajaran yang efektif, mudah diterima dan dipahami oleh peserta dibandingan dengan melibatkan dosen dalam bentuk pengayaan uji kompetensi. Tidak dapat dipungkiri bahwa Teman sebaya memberikan pengaruh signifikan pada kehidupan seseorang. Papalia (2008), menyatakan bahwa kelompok teman sebaya merupakan sumber afeksi, simpati, pemahaman, dan panduan moral, tempat bereksperimen, dan setting untuk mendapatkan otonomi dan independensi dari orang tua.

Papalia, Olds, \& Feldman (2009) dalam perkembangan manusia mengemukakan bahwa keterlibatan teman sebayanya, selain menjadi sumber dukungan emosional juga menjadi faktor tekanan dimana teman sebaya akan menjadi penyemangat untuk meningkatakan prestasi.(Papalia, d.e., olds, s.e., \& feldman, 2009) Selain dari itu Kemampuan pemahaman uji kompeteni juga merupakan kesiapan ujian yang meliputi pemahanman peserta uji kompetensi tengan blue print uji kompetensi yang meliputi butir soal, tinjauan, jumlah soal terbanyak dan strategi menjawab soa; berdasarkan pemahaman yang baik dengan soal uji kompetensi (Nugroho, 2016).

Blueprint uji kompetensi sangat penting diketahui oleh peserta uji kompetensi karean berisi raugn lingkup soal yang akan diujikan sehingga menjadi acuan dalam belajar dan menjadi focus dalam soal yang akan diujikan (Nugroho, 2016)

Hasil penelitian ini sejalan dengan penelitian yang dilakukan Takdir tahir et.all dimana terdapat hubungan antran kesiapan dan pemahaman soal uji kompetensi dengan kelulusna ui kompetensi dimana persiapan dalam menghadapi uji kompetensi sangat dibutuhkan sehingga peserta akan merasa lebih siap pada saat 
ujian dilakukan. (Hartina, Tahir, Nurdin, \& Djafar, 2018).

\section{Hasil Uji kompetensi}

Hasil penelitian menunjukan bahwa sebanyak 22 orang responden mendapatkan hasil kelulusan uji kompetensi Lulus/Kompeten. Hasil angka kelulusan uji kompetensi dapat dikategorikan sangat baik. Hal ini menunjukkan bahwa hasil yang didapatkan tidak terlepas dari keterlibatan orang lain yang mempu manjadi faktor pendukung dan penguat dalam kelulusan uji kompetensi ini. Menurut penelitian takdir tahir dkk didapatkan bahwa faktor dominan yang mempengaruhi keluusan uji kompeensi adalah keseiapan uji kompetensi yang dilakukan oleh peserta. faktor lain yang berhunbungan dengan kelulusna uji kompetensi adalah prestasi akademik dan peran insitusi pendidikan dalam mengikutsertakan dalam tryout uji kompetensi (Alvin, 2019).

Hasil penelitian lain yang dilakukan oleh Lukmanulhakim dan lenny (2017) didapatkan bahwa faktor lain yang mempengaruhi capain kelulusan uji kompetensi adalah adanya dukungan teman sebaya, dukungan keluarga dan keaktifan dalam mengikuti kegiatan persiapan uji kompetensi (Lukmanulhakim \& Pusporini, 2018).

\section{Peningkatan Uji Kompetensi dengan Pendekatan Peer Teacing.}

Berbagai metode pembelajara untuk dapat meningkatakan pencapain uji kompetensi dilakukan oleh beberapa perguruan tinggi mulai dari bimbingan belajar online sampai mendatangkan pengajar tingkat nasional namun terkadang tidak memperhatikan faktor individu peserta.

Keaktifan mahasiswa dalam pembelajaran merupakan hal yang perlu diperhatikan mahasiswa dalam upaya mencapai prestasi belajar yang optimal. Mahasiswa yang belajarnya aktif dan memiliki motivasi yang tinggi akan mampu mencapai prestasi belajar yang tinggi akan mampu mencapai prestasi belajar yang tinggi. (Supriyati, Setiawati, \& Sandayanti, 2019)

Keterkaitan motivasi para mahasiswa untuk dapat aktif dalam rangkaian program pembelajaran, tentunya tidak terlepas dari beberapa item yang telah banyak dilakukan oleh insitusi pendidikan, seperti halnya; memberikan kesempatan peluang seluasluasnya kepada mahasiswa untuk berkreativitas dalam proses belajarnya, member tugas individual dan kelompok yang kemudian di bahas secara bersama sehingga menemukan hal yang perlu dikoreksi bersama, serta menggunakan berbagai metode dan multi media di dalam pembelajaran yang salah satunya menggunakan pendekatan teman sebaya (peer-teaching) (Widianingtyas \& Bella, 2016).

Hasil penelitian ini menguatkan tentang asumsi dasar peran dan dukungan teman sebaya untuk mencapai tujuan dan harapan. Teman sebaya bukan hanya merupakan tempat menyampaikan curahan hati dan permasalahan namun juga bisa menjadi strategi pembelajaran yang efektif untuk membantu meningkatakan motivasi, kesadaran diri dan keaktifan untuk mengikuti pembalajaran yang ditetapkan. Berdasarkan hasil penelitian pendekatan Peer-teaching sebagai suatu strategi pembelajaran menjadikan proses pembelajaran lebih aktif dan kreatif dan dengan kesedaran diri akan mampu dan mau berusaha bersama teman sebaya untuk mncapai kelulusan uji kompetensi (Lesmana et al., 2016).

Penelitian Syarifah N, Ardi 2016 menjelaskan bahwa faktor yang potensial mempengaruhi keberhasilan uji kompetensi sari segi proses pendidikan yang terdiri dari segi akademik (karakteristi pembelajara orang dewasa, materi pembelajaran, pengajaran dan pembelajaran, sumbe daya dan evalusi) dan 
dari faktor non akademik (motivasi). Faktor yang laing berpengaruh terhadapt keberhasilan pencpain uji kompetesi adalah karekteristik pembelajara yang mempunya motivasi untuk lulus uji kompetensi. Motivasi lulus uji kompetensi didapatkan dari dukunga teman sebaya yang setiap saat melakukan diskusi soal dan selalu slaing meneyemangati satu sama lain sehingga target lulus uji kompetensi dapat dicapai (Andrianty S N, Findyartini A, 2016).

Penelitian Mushawir Dkk 2019 menjelaskan dalam studi literature bahwa gaya belajar berkelompok dn teman sebaya mempunyai hubungan yang signifikan bagi peserta yang lulus uji kompetensi terutama bagi peserta pertama yang mengikuti uji kompetensi. (Mushawwir, Tahir, Kadar, Khalid, \& Ahmar, 2019). Hal tersebut sejalan dengan pendapat Lawn \& Hawskil 2017 yang menyatakan bahwa gaya belajar menjadi salah satu pendukung keberhasilan kelulusan uji kompetensi pada peserta yang pertama kali mengikuti uji kompetensi tersebut (Lown, S. G., \& Hawkins, 2017). Strategi yang tepat sebagai upaya peningkatan kelulusan uji kompetensi bagi perguruan tinggi keperawatan sangat penting dilakukan. Metode pembelajaran dan gaya belajar yang saat ini diterapkan perlu mendapatkan modifikasi dengan memberikan peran teman sebaya untuk selalu mendukung dan memotivsi setiap kegiatan yang akan dilakukan. Metode peer-teaching menjadi salah satu upaya yang dapat dilakukan karena dapat meningkatakan pencapain kelulusan uji kompetensi.

Uji kompetensi juga menjadi salah satu upaya menjamin keselamatan pasien baik di rumah sakit maupun di pusat pelayanan keshatan lainnya. Uji kompetensi ini menjadi salah satu persaratan untuk dapat mengurus surat tanda registrsi sebagai legal aspek hukum dalam memberikan pelayanan kesehatan (Hadi, 2016).

\section{SIMPULAN}

Metode peer teacing dapat menjadi strategi dan metode pembeljaran yang dapat meningkatkan kelulusan uji kompetensi. Strategi ini juga hares ditunjang dengan sumber daya dan keaktifan dalam mengikuti kegiatan tersebut.

\section{UCAPAN TERIMAKASIH}

Ucapan terima kasih kami sampaikan kepada Kemenristekdikti, STIKES YARSI Mataram dan reponden yang membantu dalam penelitian yang dilakukan.

\section{REFERENSI}

Alvin. (2019). Faktor-Faktor Yang Mempengaruhi Kelulusan Uji Kompetensi Ners Indonesia (Ukni). The Indonesian Journal of Health Science, 11(1), https://doi.org/10.32528/ijhs.v11i1.2232

Andrianty S N, Findyartini A, W. R. A. (2016). Studi Eksplorasi Kemungkinan Penyebab Kegagalan Mahasiswa Dalam Uji Kompetensi Dokter Indoneisa, Studi Kasus Di Fakultas Kedokteran Universitas Abulyatama. Jurnal Serambi PTK, $\operatorname{III}(2), 1-12$.

Hadi, I. (2016). Manajeman Keselamatan Pasein (teori Dan Aplikasi).

Hartina, A., Tahir, T., Nurdin, N., \& Djafar, M. (2018). Faktor Yang Berhubungan Dengan Kelulusan Uji Kompetensi Ners Indonesia (UKNI) Di Regional Sulawesi. Jurnal Persatuan Perawat Nasional Indonesia (JPPNI), 2(2), 65-73.

Kemenkes RI, P. D. dan I. (2017). Situasi Tenaga Keperawatan Indonesia.

Kemenristekdikti, P. U. K. N. (2017). SK Hasil Ners periode III 2017. Retrieved from https://drive.google.com/file/d/1nRNCdJ3W AcTtIGKB6IS83mTKGddvGSHG/view

Krisdianto, M. A., \& Kusumawati, W. (2019). FaktorFaktor Yang Mempengaruhi Kelulusan Uji Kompetensi Ners Indonesia (UKNI). The Indonesian Journal of Health Science, 11(1), 18.

Lesmana, G. T., Wiharna, O., \& Sulaeman, S. (2016). Penerapan Metode Pembelajaran Peerteaching untuk Meningkatkan Prestasi Belajar Siswa SMK pada Kompetensi Dasar Menggunakan Alat Ukur. Journal of Mechanical Engineering Education, 3(2), 167-173.

Lown, S. G., \& Hawkins, L. A. (2017). Learning Style 
as a Predictor of First-Time NCLEX-RN Success: Implications for Nurse Educators. Nurse Educator, $\quad$ 42(4), 181-185. https://doi.org/https://doi.org/10.1097/NNE .0000000000000344

Lukmanulhakim, L., \& Pusporini, L. S. (2018). The analysis of factors influencing graduation achievement in nurse competence test of nurse profession program. Cakrawala Pendidikan, (2).

Mushawwir, A., Tahir, T., Kadar, K., Khalid, N., \& Ahmar, H. (2019). Gambaran Strategi Program Studi Keperawatan untuk Meningkatkan Kelulusan Mahasiswa dalam Uji Kompetensi. Jurnal Keperawatan Muhammadiyah, 2(2), 104-107.

Mustika, D., Artanty, W., Harjanto, T., \& Ibrahim, R. (2019). Gambaran Tingkat Kecemasan Peserta Uji Kompetensi Ners Indonesia di Daerah Istimewa Yogyakarta. Universitas Gadjah Mada.

Nugroho, A. S. (2016). Gambaran Persepsi Mahasiswa Profesi PSIK FK UGM Tentang Uji Kompetensi Ners Indonesia. Universitas Gadjah Mada.

papalia, d.e., olds, s.e., \& feldman, r. d. 2009. (2009). human development: perkembangan manusia. Jakarta: Salemba humanika.

Rahadian, D. Z. (2018). Faktor-Faktor Yang Mempengaruhi Kelulusan Uji Kompetensi Mahasiswa Profesi Ners Stikes Jenderal Achmad Yani Yogyakarta. Jurnal Wacana Kesehatan, 2(2).

Supriyati, S., Setiawati, O. R., \& Sandayanti, V. (2019). Hubungan Antara Self Efficacy (Keyakinan Kemampuan Diri) Dengan Kelulusan Retaker UKMPPD Di Universitas Malahayati. Holistik Jurnal Kesehatan, 13(1), 29-36.

Widianingtyas, S. I., \& Bella, B. (2016). Metode Pembelajaran Tutor Teman Sebaya (Peer Group) Dalam Meningkatkan Kompetensi Mahasiswa. Jurnal Penelitian Kesehatan, 3(1), 19-24. 